\title{
Electronic epidemiological query on admission: 6 clicks for global risk assessment
}

\author{
A Bispo $^{1 *}$, C Palos $^{1}$, M Ressureição ${ }^{1}$, C Alves $^{2}$, J Mapril $^{1}$ \\ From International Conference on Prevention \& Infection Control (ICPIC 2011) \\ Geneva, Switzerland. 29 June - 2 July 2011
}

\section{Introduction / objectives}

Epidemiologically Important Microorganisms (EIM) reduction is a major aim of infection control. EIM are widely spread and shared between patients in several care settings. e-health, defined as intensive use of information and communication technologies, can be a major part of this strategy.

\section{Methods}

Aiming both detection of these patients on admission and immediate implementation of procedures, Infection Control Committee (ICC) and Information Technologies team of Hospital da Luz (a high-tech, 280-bed general hospital), created an Electronic Epidemiological Query on Admission (EEQA) on the Electronic Medical Registry (EMR). EEQA comprises 6 Yes/No questions to be fulfilled by the physician in charge of admission. If at least 1 question has a positive answer (positive EEQA), it automatically generates infection control prescriptions on the EMR (specific isolation procedures for contact, airborne, droplets or Cdiff); screening cultures (nasal MRSA, rectal MRSA, VRE and MR Acinetobacter) or Cdiff toxin screening; activation of biohazard symbol and ICC information in order to follow-up.

\section{Results}

For the first 50 EEQAs (starting on February), 70\% were positive, resulting on measures implemented for 35 patients, with $77 \%$ global sensitivity. MRSA is the main EIM (67\% sensitivity for patients who were admitted with history of health-care or long-term care stay for at least 3 days in the past 3 months).

\section{Conclusion}

The implementation of the EEQA is an innovative approach that uses the e-health concept, allowing immediate automatic detection of high risk patients on admission, avoiding the gap of time until release of screening results. With 6 clicks, $6^{6}$ different protocols can be generated without any additional effort to physicians, improving quality of care.

\section{Disclosure of interest}

None declared.

\section{Author details}

${ }^{1}$ Hospital Da Luz, Portugal. ${ }^{2}$ Siemens Medical Solutions, Lisbon, Portugal.

Published: 29 June 2011

doi:10.1186/1753-6561-5-S6-P34

Cite this article as: Bispo et al.: Electronic epidemiological query on admission: 6 clicks for global risk assessment. BMC Proceedings 20115 (Suppl 6):P34.
Submit your next manuscript to BioMed Central and take full advantage of:

- Convenient online submission

- Thorough peer review

- No space constraints or color figure charges

- Immediate publication on acceptance

- Inclusion in PubMed, CAS, Scopus and Google Scholar

- Research which is freely available for redistribution
() Biomed Central

\section{Biomed Central}

(c) 2011 Bispo et al; licensee BioMed Central Ltd. This is an open access article distributed under the terms of the Creative Commons Attribution License (http://creativecommons.org/licenses/by/2.0), which permits unrestricted use, distribution, and reproduction in any medium, provided the original work is properly cited. 